UDK 630*9(497.6 Unsko-sanski kanton)“2003/2013“

\title{
INFLUENCE OF THE FOREST FOCUSED LEGISLATION ON THE INVESTMENTS IN FOREST SECTOR OF THE FEDERATION OF BOSNIA AND HERZEGOVINA - CASE STUDY UNA-SANA CANTON
}

Uticaj zakonske regulative na investicije u sektoru šumarstva u Federaciji Bosne i Hercegovine - studij slučaja Unsko-sanski kanton

Sabina Delić ${ }^{1}$, Mersudin Avdibegović ${ }^{1}$, Senka Mutabdžija Bećirović ${ }^{1}$, Dženan Bećirović ${ }^{1}$, Bruno Marić ${ }^{1}$, Amel Pašić ${ }^{1}$

\begin{abstract}
Investments in forest sector represent an important issue that is regulated by legislation. Legislative framework that regulate forest sector in the Federation of Bosnia and Herzegovina has been changing recently - from the Law on Forests of the Federation of Bosnia and Herzegovina (2002 - 2009), Forest Regulation of the Federation of Bosnia and Herzegovina (2009 - 2012) and finally cantonal Laws on Forests (2012 to date). Cantonal laws currently represent the only valid legislative documents that regulate forest sector in the Federation of Bosnia and Herzegovina. This paper analyse the investments in the public forests at the territory of Una-Sana Canton, managed by forest management enterprises "Unsko-sanske šume", within the period 2003-2013 in dependence of the valid legislative frameworks. Having in mind the various regulations that prescribed the financing of the biological investments, scope and structure of the performed activities together with the amount of invested funds have varied between particular periods. The biggest share in total investments to forest sector belongs to the silvicultural measures $(66 \%)$ and forest road construction (17\%). The analysis included the trend of realised biological investments and invested funds. It reveals the mutual incompatibility that causes the differences in unit costs of biological investments in various periods. This implies the need for creation and implementation of unique methodology for cost calculation respecting the basic principles of econometrics. Conducted analysis indicated that previous legislative frameworks did not prescribe appropriate financing model. One should bare in mind this fact during the prescription of new financing model in the ongoing proposal of new Law on Forests of the Federation of Bosnia and Herzegovina.
\end{abstract}

Key words: Investments, Law on Forests of the Federation of Bosnia and Herzegovina, Forest Regulation, Cantonal Law on Forests, Una-Sana Canton.

1 Faculty of Forestry University of Sarajevo 


\section{INTRODUCTION - Uvod}

Forestry is economic activity responsible for one of the most important natural resources that represent a cornerstone for both life-sustaining and survival of mankind (RANKOVIĆ, 1996). Fulfilment of various societal needs for wood and non-wood forest products together with ensuring of appropriate provision of various ecological and social functions of forest ecosystems represent the main task of forest sector. In order to secure sustainable management of forest resources, continuous investments in maintenance of forest productivity and harmonization of their usage with its actual potential is crucial (SCHMITHÜSEN et al., 2006). Investment decision making is related with provision of financing opportunities as well as modes for cost-efficiency evaluation in forestry (KEČA et al., 2011; KEČA et al., 2012).

In spite of growing awareness on importance for investing in forest sector, many countries failed to find an adequate way for solving this issue. Lately, international financial organisations have been increasing the level of financing in forest sector but this is still not enough (TOMASELLI, 2006).

Due to its specificities, forestry is unattractive sector for investments. As forest users, forest enterprises are lacking the motivation for investments due to the slow capital turnover and far-reaching economic effects of such investments (DELIĆ et al., 2011a). Therefore, investments in current forest practice in the Federation of Bosnia and Herzegovina (hereinafter FB-H) could mainly be equated with fulfilment of the obligations prescribed by the Law (DELIĆ et al., 2011b). In previous regimes, investments in forest sector of Bosnia and Herzegovina (hereinafter B-H) were realized in accordance with current economic trends in society. Various, often administrative, measures were adopted and caused negative and irreparable consequences on forest sector, its economic viability and developing potential (DELIĆ, 2006).

Legislative framework that regulate forest sector in the FB-H has been changing recently. Firstly there were Law on Forests of the FB-H, after which Forest Regulation of the FB-H while currently cantonal Laws on Forests represent the only valid legislative documents that regulate forest sector in the FB-H. Investments in forest sector represent an important issue that is regulated by legislation. Cantonal forest management enterprises (hereinafter FMEs), established by the Law on Forests of the FB-H from 2002, are users of public forests in the FB-H. FMEs were obliged to allocate funds for simple and extended biological reproduction of forests (Article 25 of the Law on Forests of the FB-H from 2002). This Law prescribed the activities of simple and extended biological reproduction, method for allocation, recording and spending of these funds (Article 26). After decision to proclaim Law on Forests of the FB-H from 2002 as invalid, in order to temporary regulate forest sector, the Government of the FB-H had adopted the Forest Regulation in November 2009 that was in force until the end of 2011. This regulation prescribed that users of public 
forests (FMEs) were obliged to conduct biological reproduction minimally at the level prescribed by forest management plan (Article 7). After the termination of validity of this Regulation, cantons of the FB-H had adopted the cantonal legislative documents. These documents regulate differently the issues of forest management, forest governing, and allocation of funds for usage, protection and improvement of forests. Due to the changes in legislative framework and various regulations that prescribed the financing of the biological investments, scope and structure of the preformed activities together with the amount of invested funds have varied between particular periods. In order to analyse the influences of regulations on investments in forest sector, this research had been conducted at the territory of Una-Sana Canton.

The general model of multifunctional forestry financing stress out importance of mutual compatibility between interests of forest owners, other stakeholders and public (SCHмітнÜSEN et al., 2006).

\section{MATERIALS AND METHODS - Materijali i metode}

Public forests at the territory of Una-Sana Canton have been managed by Forest Public Enterprise "Unsko-sanske šume" Ltd Bosanska Krupa (hereinafter FPE "Unsko-sanske šume"). This enterprise is responsible for the management of 179.977 ha of forests and forest land. When it comes to the organisational structure, this FPE has seven organisational units (5 local forest management units, 1 nursery production unit and 1 unit for construction activities, mechanisation and maintenance), Direction with its inner sectors and Unit for forest management distributed in six municipalities of Una-Sana Canton. In the last 15 years, FPE has been annually distributed around $400.000 \mathrm{~m}^{3}$ of wood assortments on average. In other words, FPE realized average annual income of around 31 million KM and profit of around 1 million KM. Average number of employees was 604, while FPE owns FSC certificate (Web page of the FPE "Unsko-sanske šume" Ltd, 2016) since 2011.

According to the goal of the research, it was assumed that the amount of invested funds in forest sector is in correlation with the scale of production and total income realized by FPE. This research analyzes the period from $2003-2013$ when three legislative solutions have been applied: Law on Forests of the FB-H from 2002, Forest Regulation from 2009 and Law on Forests of Una-Sana Canton from 2012.

Main sources of information that have been used for the research are Annual reports and Annual work plans of FPE "Unsko-sanske sume" for the period 20032013, forest management plans for forest management areas within Una-Sana Canton, forest related legislative documents and other literature sources.

After data collection and creation of data basis, their analysis had been conducted by applying proper methods, techniques and statistical tools. Methods of theoretical analysis, comparison, synthesis and normative method were applied. 
Furthermore, the trend analysis, basic and chain index analysis were used as indicators of investments in silvicultural activities during analysed period. Statistical data analysis was conducted by the application of Microsoft Excel 2007 programme.

\section{RESULTS AND DISCUSION - Rezultati i diskusija}

\section{Analysis of regulations concerning financing of the investments in forestry - Analiza zakonskih odredbi o finansiranju investicionih ulaganja}

According to the regulations of the Law on Forests of the FB-H from 2002, cantonal FPE, as forest users had obligation to allocate funds for simple and extended forest reproduction in the amount of $15 \%$ of the following operating parameters of the FPE: total annual income generated by selling the wood assortments and value of the wood used for the needs of the FPE as well as the income generated by selling of the non wood forest products. Additionally, cantonal FPE was obliged to allocate additional $3 \%$ of the same operating parameters for extended forest reproduction. Out of the funds intended for the simple forest reproduction, following activities could be financed: creation of forest management plans, implementation projects, soil preparation for the natural forest regeneration, artificial (man-induced) afforestation of clear cuts and recently formed fire sites in forests and forest lands, selection of trees for cuttings, silvicultural measures, forest protection from pests, diseases, forest fires and illegal usurpations, production of seeds and planting materials, forest road construction, game management and other activities stemming from the need to secure sustainable forest management. Scopes of these activities were determined by forest management plan. Furthermore, they should be harmonized with Forest programme of the FB-H and cantonal forest development plans. Having in mind that none of these documents were adopted during the validity period of this Law, forest management plan was the basic document for creation of annual (operational) plans. Funds for extended biological reproduction could be used for regeneration of degraded and coppice forests, afforestation of karst and bare land and improvement of ecological and social forest functions (Articles 26 and 27). Apart from these financial sources, all legal entities that operate at the territory of the FB-H were obliged to pay compensation for usage of ecological and social functions of the forest ecosystems in the amount of $0.1 \%$ of their income (Article 60). Together with funds for extended biological reproduction, these funds were paid into special funds (budgets) by following distribution: $20 \%$ to the special fund of the budget of the FB-H and $80 \%$ to the budget of the canton (Scheme 1). 


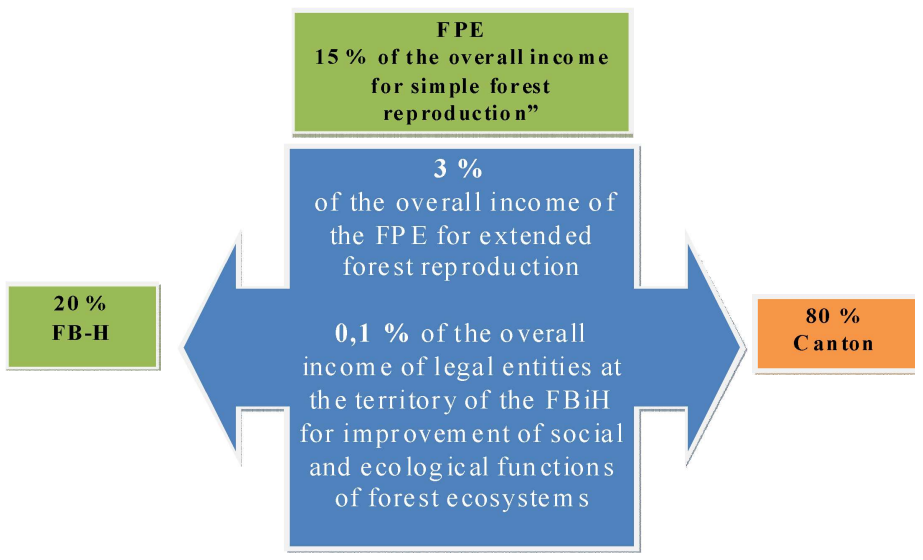

Scheme 1. Financial scheme according to the Law on Forests of the FB-H from 2002 Šema 1. Finansiranje prema Zakonu o šumama FB-H, 2002.

After proclaiming the Law on Forests as unconstitutional, in 2009 the Government of the FB-H adopted the Forest Regulation. Financing issues were regulated differently by the Forest Regulation. Regulation prescribed that FPEs should paid a tax for forest usage in the amount of $7 \%$ of their income that is generated by selling of wood assortments and non wood forest products. The total income of sold wood was calculated based on their stumpage price. Funds collected by this methodology were distributed as follows: $5 \%$ to the special account of the municipality where the taxed income had been realised and per $1 \%$ to the special accounts of the budgets of the FB-H and cantons. Tax for ecological and social forest functions was reduced to the $0.07 \%$ with retention of same distribution to the federal and cantonal levels (Scheme 2).

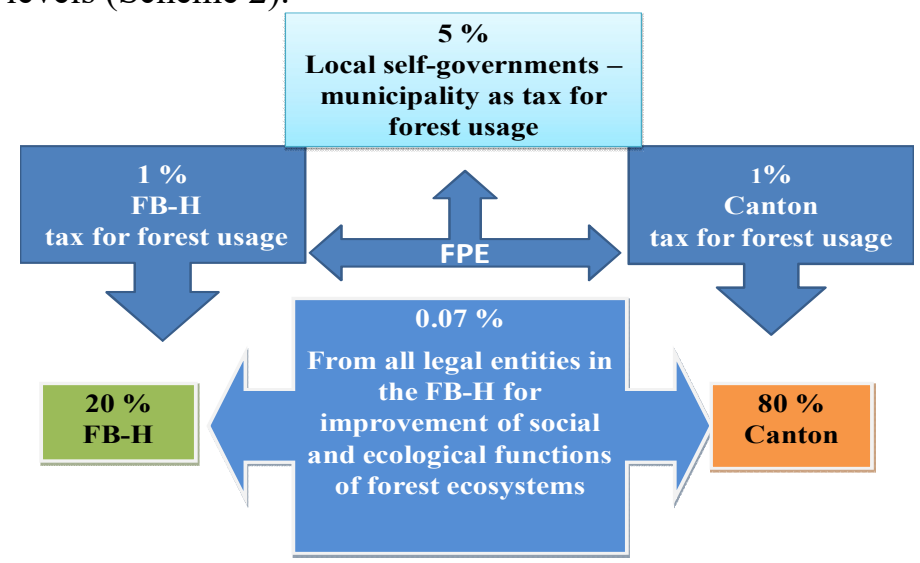

Scheme 2. Financial scheme according to the Forest Regulation from 2009 Šema 2. Finansiranje prema Uredbi o šumama FB-H, 2009. 
Law on Forests of the Una-Sana Canton was adopted in 2012. FPE "Unskosanske šume" operates according to this Law due to the absence of the Law on Forests of the FB-H. According to this cantonal law, users of public forest and private forest owners are obliged to execute minimal measures of biological reproduction that are proposed by forest management plan and in accordance with cantonal forest development plan (Article 16). FPE pays tax for using of public forests in the amount of $9 \%$ of the total income realised by selling of wood assortments (calculated by the stumpage price) and non wood forest products. According to the Article 53, funds from this tax are distributed by following methodology: $4 \%$ to the special account of the cantonal budget and 5\% to the special account of the local government unit. By comparing regulations prescribed by this legislative solution and previous ones (especially the Law on Forests of the FB-H from 2002), this law has increased the obligations of FPE to local government units and Canton. Such legislative solution has decreased the accumulative and reproductive ability of the FPE and by that - capacity to invest in forest ecosystems. Tax for using social and ecological forest functions, that should be paid by all legal entities registered at the territory of the Canton, is $0,07 \%$ of their total income and is paid to the special account of the Canton. This analysis revealed complete omission of the federal level in the distribution of the funds collected as compensation for using forest functions. In other words, this legislative solution excluded the FB- $\mathrm{H}$, as owner of the public forests, from managing the forests ecosystems at the territory of this canton (Scheme 3).

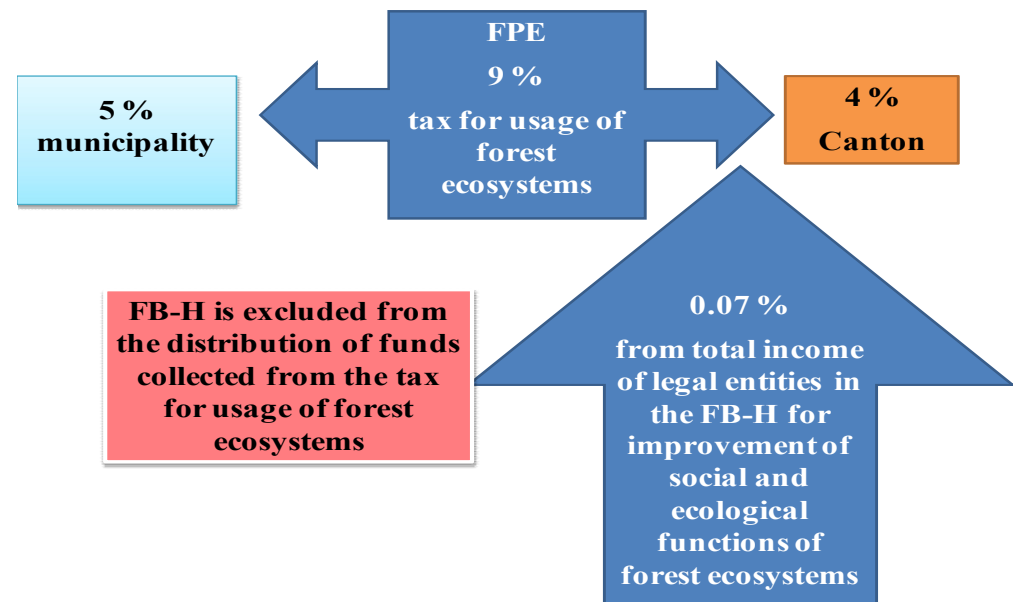

Scheme 3. Financial scheme according to the cantonal Law on Forests from 2012 Šema 3. Finansiranje prema Kantonalnom zakonu o šumama, 2012. 


\section{Forest investments and their structure at the territory of the Una-Sana Canton - Investicije i struktura investicionih ulaganja na području Unsko-sanskog kantona}

The most important factors that influence the FPE ability to invest are: scope and structure of the produced wood assortments, revenues and expenditures, business result, number and structure of employees and openness of the area and the market regarding the product placement. Due to these characteristics, it is often debated about the ability of forest enterprises to realize the real investment needs. In this regard, arises the need for creation of model for financing the forest investments that should include both direct and indirect forest users. In the structure of total investments, following categories were analysed: silvicultural measures (biological investments), forest road infrastructure, forest transportation equipment (vans, mini buses, terrain vehicles, heavy mechanisation, trucks and similar), buildings and other investments (IT equipment, geodetic and equipment for dendrometry, preparation of forest management plan, professional trainings and similar).

According to the forestry regulations, silvicultural measures refers to: land preparation for reforestation, artificial (man-induced) afforestation of bare lands by using seedlings, artificial (man-induced) afforestation of bare lands by using seeds, replanting, nurturing and thinning of forest plantations, thinning of forest stands, remediation of fire sites, reclamation of degraded forests to high forests and other activities that are referring to establishment, nurturing and improvement of overall condition of forests. The implementation extents of planned silviculuture measures and overall amount of invested funds at the territory of Una-Sana Canton have been presented at the Figures 1 and 2.

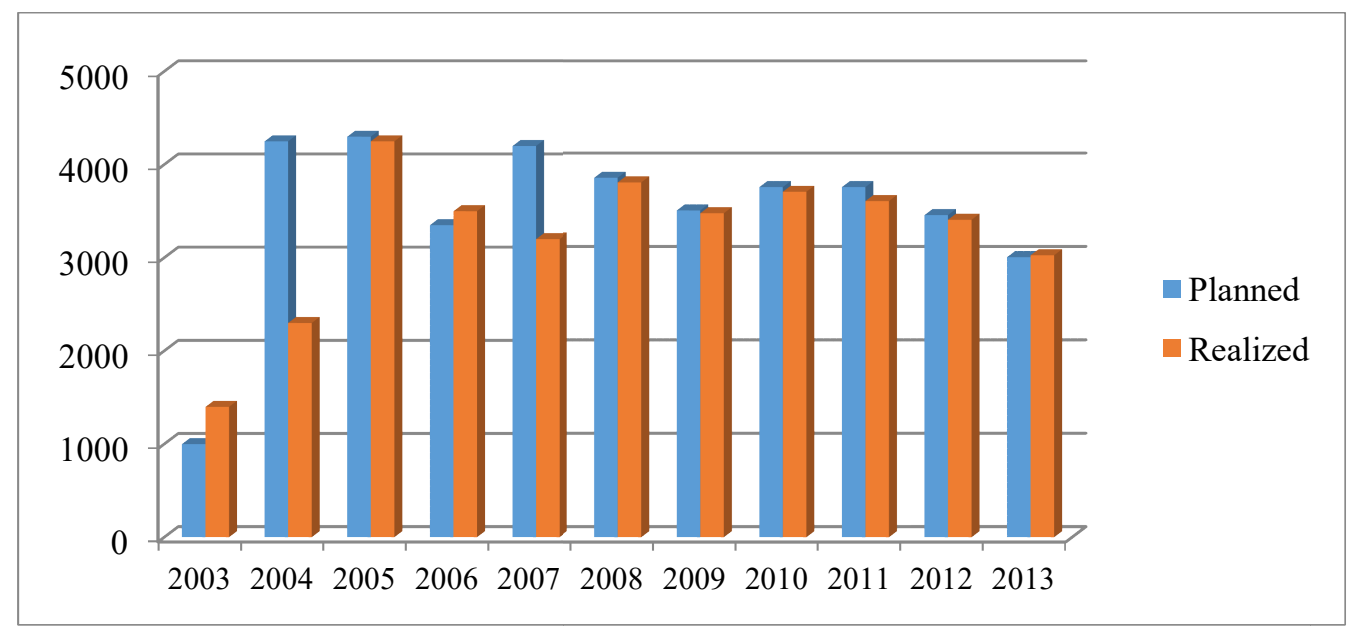

Figure 1: The scope of planned and realized silvicultural measures (ha)

Grafikon 1. Obim planiranih i ostvarenih šumskouzgojnih radova (ha) 


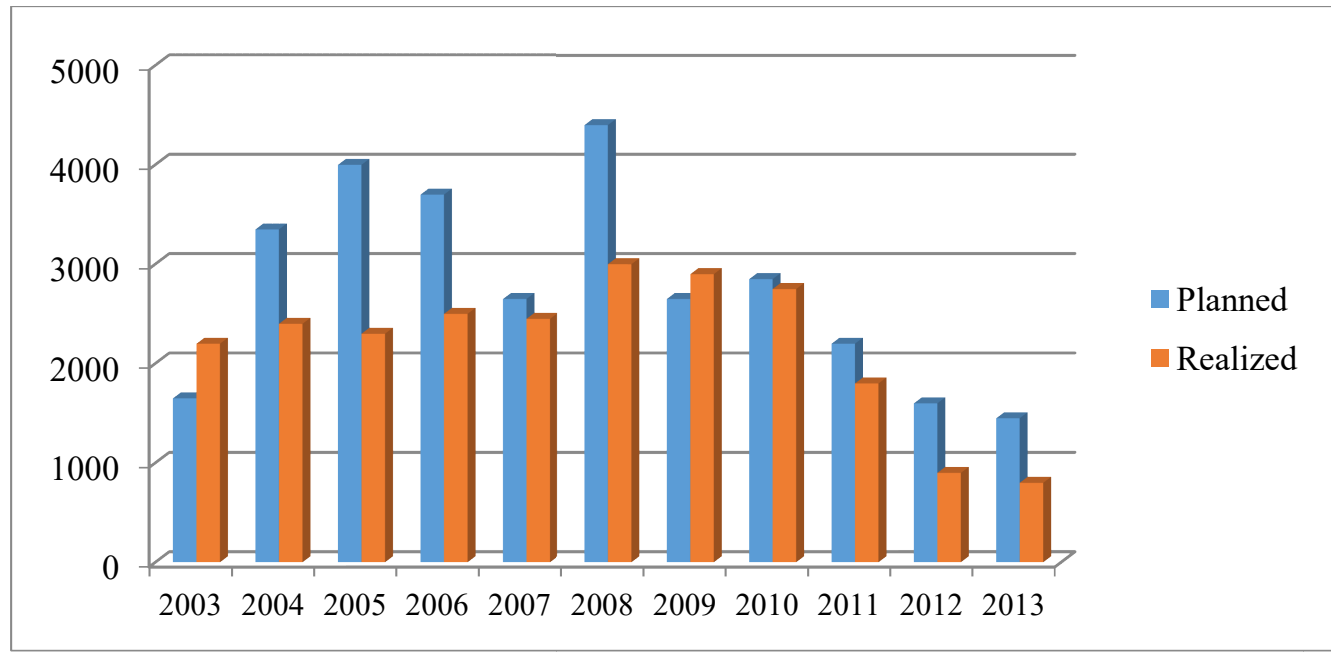

Figure 2: Planned and realized investments in silvicultural measures (1000 KM)

Grafikon 2. Planirane i ostvarene investicija u šumskouzgojne radove (1000 KM)

During the period of validity of the Law on Forests of the FB-H from 2002, average scope of realization of silvicultural measures were 3.140 ha which makes $90 \%$ of planned measures. 2.5 million $\mathrm{KM}$, or $80 \%$ of planned funds, were invested annually. Investing trend was in slow progress during this period with maximum achieved in 2008 (Figure 3).

The trend of realization of planned and realized scope of silvicultural measures during the validity of the Forest Regulation had been in slow progress. On the other hand, the amount of funds invested was decreasing in a way that the funds invested in 2011 were 33\% lower than those in 2010 (Figure 4). Such opposite trends could be explained with endeavour of FPE to rationalise its expenses for sivicultural measures by engagement of all employees in their realisation (Annual Report of the FPE "Unsko-sanske šume" for 2010 and 2011). 
Influence of the forest focused legislation on the investments in Forest sector of the Federation of Bosnia and Herzegovina - Case study Una-sana canton

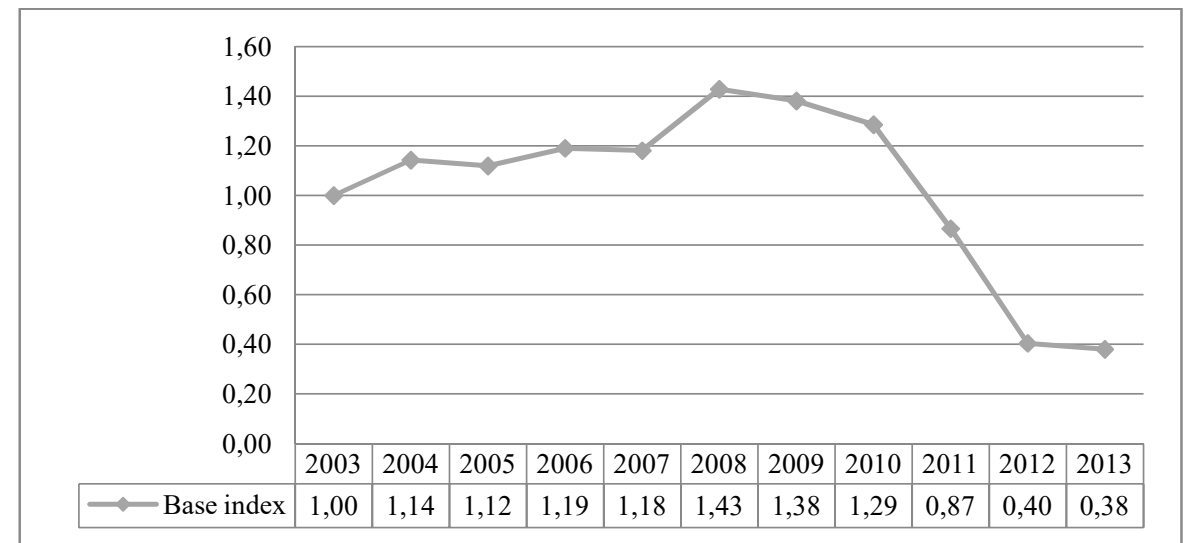

Figure 3: Base index of realised investments in silvicultural measures Grafikon 3. Bazni indeks ostvarenih investicija u šumskouzgojne radove

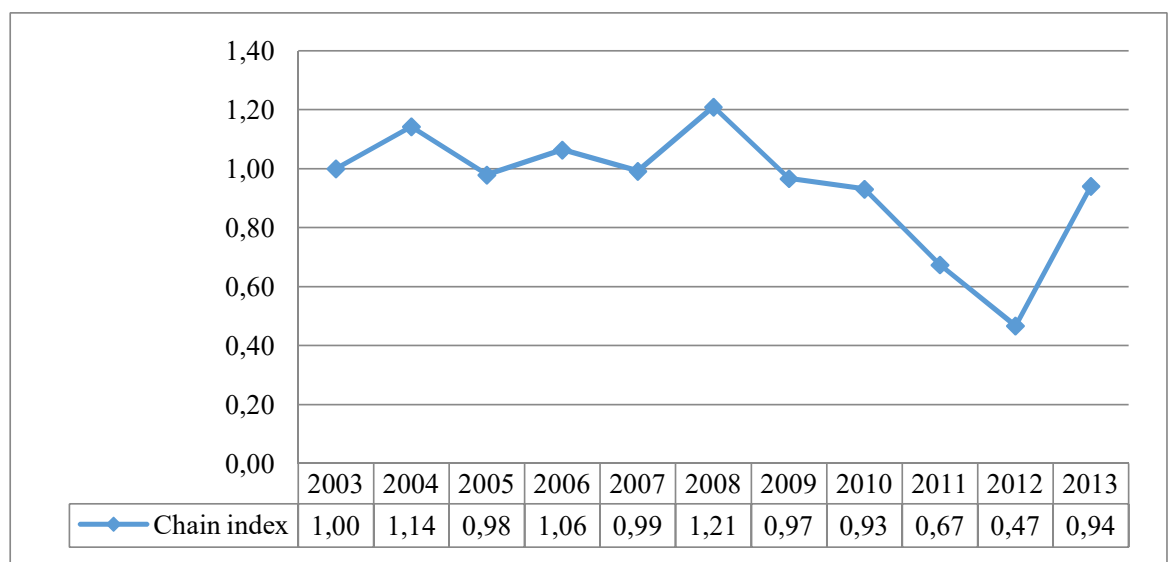

Figure 4: Chain index of realized investments in silvicultural measures

Grafikon 4. Lančani indeks ostvarenih investicija u šumskouzgojne radove

During the validity of the cantonal Law on Forests, the trend of decreasing realisation of silvicultural measures and funds invested has been continued. Average scope of realized silvicultural measures in this period were lower for around $10 \%$ in comparison to the period of implementation of Forest Regulation while invested funds were $36 \%$ smaller.

Absence of correlation between scope of silvicultural measures and invested funds in periods of implementation of different legislative solutions derives differences in unit costs of silvicultural measures. According to the calculation of invested funds for silvicultural measures in period of implementation of the Law on Forests of the FB-H, average investments for 1 ha of forests was $807 \mathrm{KM}$, in period of 
Forest Regulation $623 \mathrm{KM}$ while during the implementation of cantonal Law, unit costs for realisation of silvicultural measures was $264 \mathrm{KM}$.

The scope of planned and realised investments in construction of forest road infrastructure and annual investments in analyzed period are given at the Figures 5 and 6. During the validity of the Law on Forests of the FB-H, average annual scope of construction of forest road infrastructure was $12.2 \mathrm{~km}$ while average annual invested funds was $600.000 \mathrm{KM}$. This period had growing investing and construction trends. In implementation period of the Forest Regulation, scope of forest road construction was $50 \%$ lesser annually in comparison to the implementation period of previous legislative solution. Average annual investments were $25 \%$ lesser as well.

In the validity period of the cantonal Law on Forests, average annual scale of forest road construction is $11 \mathrm{~km}$ with increased annual investments for around $45 \%$ in comparison to the previous period.

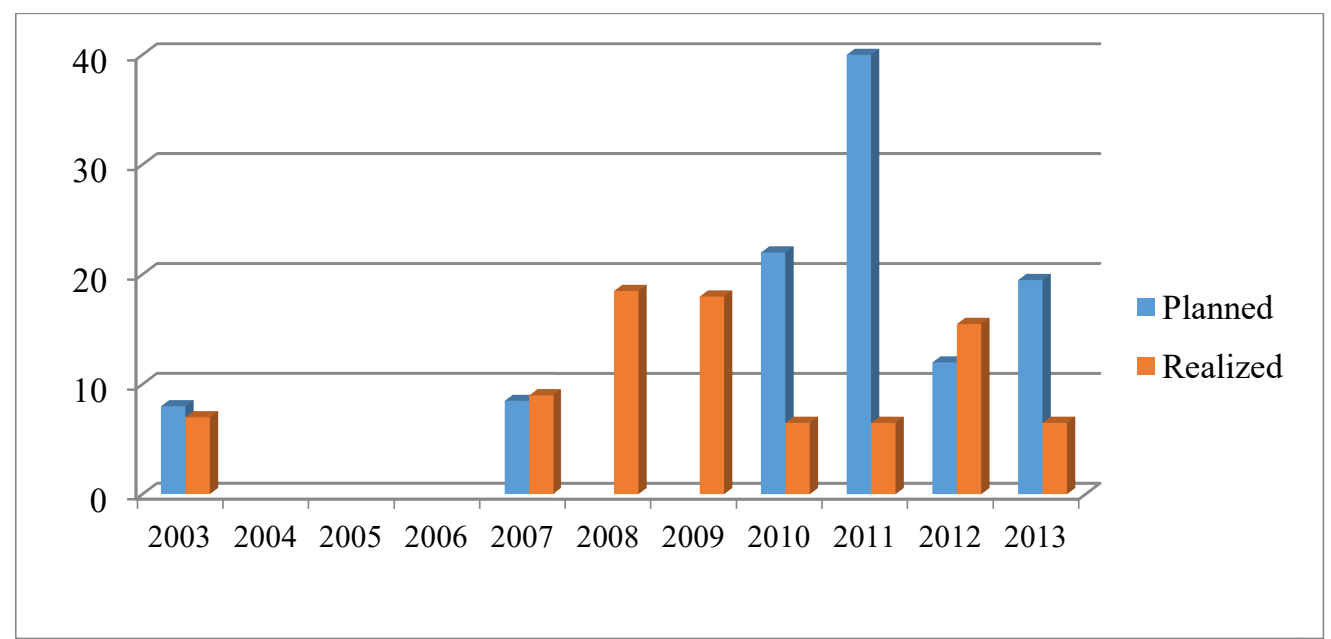

Figure 5. The scope of planned and realized forest road construction activities $(\mathrm{km})$

Grafikon 5. Obim planirane i ostvarene izgradnje šumskih komunikacija (km) 


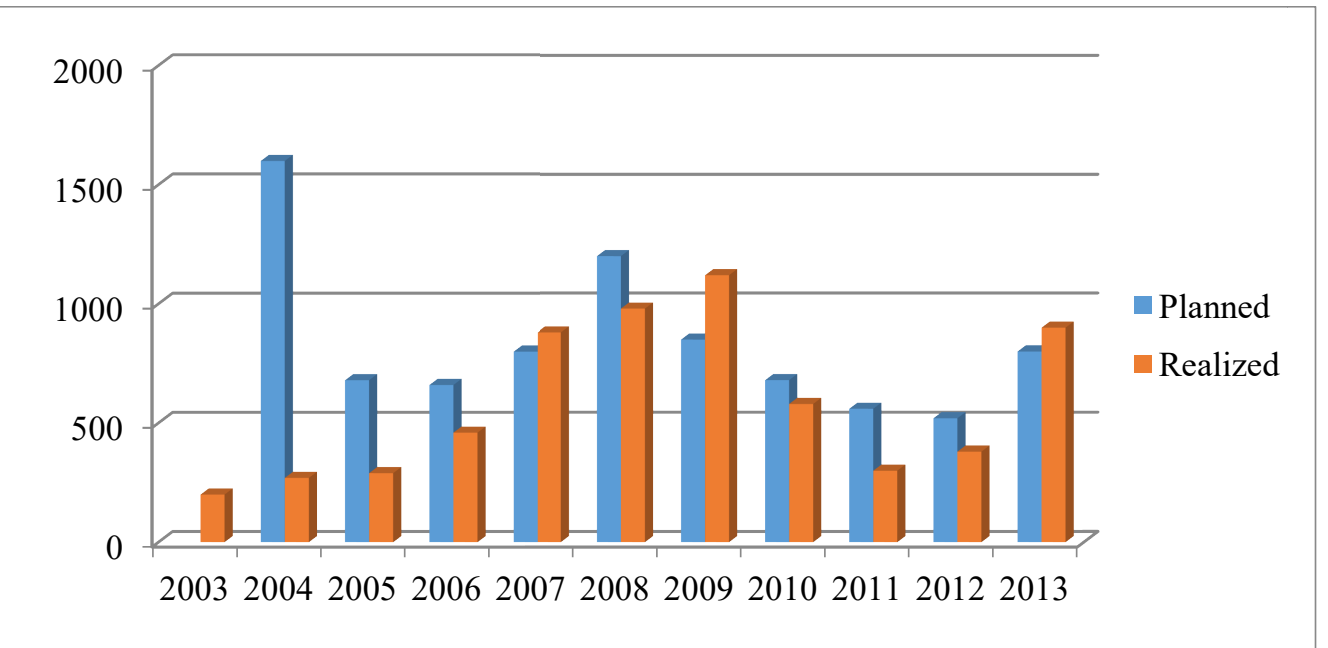

Figure 6. Planned and realized investments in forest road construction (1000 KM)

Grafikon 6. Planirana i ostvarena ulaganja u izgradnju šumskih komunikacija (1000 KM)

Trends of funding the other investments in forestry (such as forest and transport mechanisation, buildings etc) is similar to the trend of forest road construction. Their scope in total investments for the analysed period is around $17 \%$. The biggest amount of invested funds in the analysed period is referring to the investments in silvicultural measures. It accounts for around $66 \%$ of total investments while investments in forest road construction make around $17 \%$.

\section{CONCLUSIONS - Zaključci}

In the analyzed period (2003-2013), three legislative solutions were in force. They significantly differ among themselves in terms of regulations that prescribe the funds allocation for forestry investments. Consequently, these legislative solutions had different effects on the trends of both realisations and investments in biological forest reproduction.

Investments in silvicultural measures (biological reproduction) in analyzed period makes $66 \%$ out of the total investments, $17 \%$ of the investments are referring to the forest road construction while rest of the funds refers to other investments (such as forest and transport mechanisation, buildings etc). Despite of the increasing production trend and income increase in FPE "Unsko-sanske šume" in this period, there were no investing increases in biological reproduction. Opposite to that, results of the analysis revealed decreasing trends in analysed periods and illogical correlations between scope of realized silvicultural measures and funds invested. It resulted with differences in unit costs of particular silvicultural measures that leads to the questioning of objectivity of cost calculations that report costs which are lower 
that their actual value. This leads to the questioning of realisation of biological reproduction and cost calculations during the period of implementation of the Law on Forests of the FB-H that prescribes funds allocations to the dedicated subaccount. It indicates a need for implementation of unique methodology for costs calculations of all silvicultural measures and other measures from the sphere of biological reproduction by respecting the principles of cost calculations and regardless to the prescribed models of their financing. This will lead to the creation of preconditions for determination of real value of biological reproduction in forestry, actual needs for investments in forestry and it will enables the creation of effective model for funding the investments in forestry. It is of particular importance to the forest owner and to the FPEs, as forest users, as well.

Cantonal Law on Forests increases obligations of the FPE to the local governmental units (municipalities) and Canton in comparison to the previous legislative solutions. It caused the decreasing in accumulative and reproductive abilities of the FPE and its abilities to allocate funds for investments.

The conducted analysis revealed how previous legislative solutions failed to deliver effective financing model that should assure sustainable development of forest sector. Absence of the Law on Forests at the level of the FB-H totally excludes forest owner (the FB-H) from the processes of decision making and financial flows in forest sector of the FB-H which represent a peculiar absurd.

For adequate establishment and strengthening of institutional duties and responsibilities over forest management and forest governing, it is necessary to adopt an adequate Law on Forests that should enable accomplishment of overall interests and long-term principles of sustainable forest management at the territory of the FB-H and Una-Sana Canton.

In order to achieve efficiency and operability in forest management and forest governing, it is important to satisfy interests at various governmental levels, including those at the level of local self-governments along with ensuring of the adequate system that controls the expenditure of allocated funds.

Results of this research could be important factor in the process of preparing new legislative framework of forest sector in the FB-H. Moreover, it could be used in the development of financing model that should recognize, account and respect longterm production process, different conditions for production and multifunctional nature of forest ecosystems. 


\section{REFERENCES - Literatura}

DELIĆ, S. (2006): Istraživanje modela finansiranja biološke reprodukcije u šumarstvu $\mathrm{BiH}$, Doktorska disertacija, Šumarski fakultet, Sarajevo.

Delić, S., Pružan, E., Pozderac, M. I BajRić, A. (2011a): Planiranje, ekonomika i marketing šumarskog poslovanja, Studija, FMPVŠ, Sarajevo, [Available at http://goo.gl/Nc4mDC].

Delić, S., Pružan, E., Pozderac, M. (2011b): [Finansiranje multifunkcionalnog šumarstva, Studija, finalni izvještaj, FMPVŠ, Sarajevo, [Available at http://goo.gl/Nc4mDC].

INFORMACIJE o gospodarenju šumama u Federaciji BiH (period 2003. - 2013.), FMPVŠ, [Available at http://goo.gl/9aRgHM].

IZVJEŠTAJI o radu ŠPD "Unsko-sanske šume" za period 2003. - 2013.

KEČA LJ., KEČA N., PAJIĆ S. (2011): Investment Appraisal of Poplar Plantations in Serbia, Baltic Forestry 17(2), (268-279), (IF 0,532) (ISNN1392-1355).

KEČA LJ., KEČA N., PANTIĆ D. (2012): Net Present Value and Internal Rate of Return as Indicators for Assessment of Cost-efficiency of Poplar Plantations: a Serbian case study, International Forestry Review 14(2), Commonwealth Forestry Association, (145-157) (IF 1, 263) (ISNN 1465-5489).

PAŠıć, A. (2015): Analiza investicija u sektor šumarstva na području Unsko-sanskog kantona, Master rad, Šumarski fakultet Univerziteta u Sarajevu.

RANKović, N. (1996): Ekonomika šumarstva, Šumarski fakultet Univerziteta u Beogradu, Beograd.

Schmithüsen, F., Kaiser, B., Schmidhauser, A., Mellinghoff, S., Kammerhofer, A. W. (2006): Preduzetništvo u šumarstvu i drvnoj industriji: Osnove menadžmenta i poslovanja, prevod, Ekonomski fakultet u Beogradu, Beograd.

TomAselli, I. (2006): Brief Study on Funding and Finance for Forestry and Forest Based Sector, Final report, UNFF, Brazil, [Available at http://goo.gl/b5Rd67]

UREDBA O ŠUMAMA (Službene novine Federacije BiH, broj: 83/09, 26/10, 38/10 i 60/11).

Web PAGE OF THE FPE "UNSKO-SANSKE ŠUME" Ltd, 2016: Petnaest godina poslovanja ŠPD "Unsko-sanske šume" d.o.o. Bosanska Krupa, [Available at http://goo.gl/RnE2Hr]

ZAKON O ŠUMAMA (Službene novine Federacije BiH, broj 20/02, 29/03, 37/04).

ZAKON O ŠUMAMA UNSKO-SANSKOG KANTONA (Službeni glasnik US kantona broj 22/12).

\section{SAŽETAK}

U cilju obezbjeđenja održivog gospodarenja šumskim resursima, neophodno je kontunuirano investiranje i usklađivanje načina korištenja šuma sa raspoloživim potencijalom. Zbog svojih specifičnosti, šumarstvo je neatraktivan sektor za 
investiranje, tako da je neophodno zakonom definisati adekvatan model finansiranja investicija u šumarstvo. U iznalaženju općeg modela finansiranja multifunkcionalnog šumarstva bitno je postići usaglašenost interesa vlasnika šuma, svih zainteresovanih korisnika kao i javnosti. U cilju analize uticaja zakonskih odredbi na investicije u sektoru šumarstva, provedeno je istraživanje na području Unsko-sanskog kantona. Od ukupnih investicija u šumarstvo u analiziranom periodu od 2003. do 2013. godine, oko $66 \%$ se odnosilo na investicije u šumskouzgojne radove (biološku obnovu), 17\% su bile investicije u izgradnju šumskih komunikacija, a sve ostale investicije (šumska i transportna mehanizacija, građevinski objekti i sl.) su činile 17\%. U analiziranom periodu su na snazi bila tri zakonska rješenja i to: Zakon o šumama Federacije BiH iz 2002. godine, Uredba o šumama iz 2009. godine i Zakon o šumama Unsko-sanskog kantona od 2012. godine u uslovima nepostojanja zakonskog okvira za nivo Federacije $\mathrm{BiH}$.

Zakonom o šumama FB-H je bilo predviđeno da šumskoprivredna društva vrše obavezno rezervisanje sredstava u iznosu od $15 \%$ od prihoda ostvarenih prodajom drveta za izvršenje jednostavne biološke reprodukcije, a na ime proširene reprodukcije iznos od 3\%. Sredstava za proširenu reprodukciju su se alocirala na nivo FB-H i Kantona u omjeru 20:80. U ovom periodu je trend investicionih ulaganja bio u blagom porastu, uz maksimalan index 1,4 u 2008. godini u odnosu na baznu 2003. godinu.

Uredba o šumama je donijela novinu u načinu finansiranja biološke obnove, pri čemu se ne razdvajaju pojmovi proste i proširene biološke reprodukcije, a uvodi se obaveza plaćanja naknade za korištenje šuma. Šumskoprivredna društva su bila obavezna plaćati lokalnoj zajednici naknadu u iznosu $5 \%$ od prihoda ostvarenog prodajom šumskih drvnih proizvoda, dok se za kantonalni i federalni nivo izdvajala po $1 \%$. Uredbom o šumama nije bila propisana obaveza rezervisanja sredstava za biološku reprodukciju na poseban podračun, ali su šumskoprivredna društva bila dužna realizirati planove šumskoprivredne osnove. U ovom periodu je nastavljen rastući trend planiranog i realizovanog obima šumskouzgojnih radova, ali je iznos uloženih finansijskih sredstava bio u opadanju. Kao posljedica toga je javljaju različite jedinične cijene pojedinih šumskouzgojnih radova u uslovima različitih modela finansiranja, što dovodi u pitanje objektivnost kalkulacije troškova. Iz ovog proizlazi potreba izrade i primjene jedinstvene metodike kalkulacije troškova svih šumskouzgojnih i ostalih radova iz područja biološke obnove, poštujući principe kalkulacije troškova, bez obzira na propisani model njihovog finansiranja. Na taj način bi bili stvoreni preduslovi za utvrđivanje realne vrijednost biološke reprodukcije $u$ šumarstvu, stvarnih potreba za ulaganjem u šumarstvo, te omogućeno kreiranje efikasnog modela finansiranja investicija. To ima posebnu važnost za vlasnika šuma, a takođe i za sve druge korisnike.

Kantonalnim zakonom o šumama se povećavaju ukupne obaveze šumskoprivrednog društva prema lokalnim zajednicama (općinama) i Kantonu u odnosu na prethodno zakonsko rješenje, što značajno utiče na smanjenje akumulativne i reproduktivne 
sposobnosti preduzeća i mogućnosti investicionog ulaganja. U ovom periodu se nastavlja opadajući trend realizacije šumskouzgojnih radova i uloženih sredstava. Prosječan obim izvršenih šumskouzgojnih radova u ovom periodu je bio niži za oko $10 \%$ u odnosu na period važenja Uredbe o šumama, dok su ukupno uložena sredstva bila manja za $36 \%$. Kantonalnim zakonom o šumama se u potpunosti izostavlja federalni nivo u sistemu raspodjele sredstava od naknada za šume. Nepostojanje federalnog Zakona o šumama ima za posljedicu isključenje vlasnika (Federaciju B-H) iz procesa odlučivanja i svih finansijskih tokova u šumarstvu Federacije B-H, što predstavlja apsurd.

Rezultati ovog istraživanja mogu imati značaja u procesu izrade zakonske regulative iz oblasti šumarstva FB-H i razradi modela finansiranja u šumarstvu, pri čemu je potrebno uvažavati dugoročni karakter procesa proizvodnje, različite uslove privređivanja preduzeća šumarstva kao i multifunkcionalnost šumskih resursa.

Faculty of Forestry University of Sarajevo, Zagrebačka 20, 71000 Sarajevo, Bosnia\&Herzegovina. *Corresponding author: s.delic@sfsa.unsa.ba; 